\title{
ARCHAELOGY
}

Albert E. N. Swanston

How many readers are interested in archaelogy, that fascinating natural history science which deduces a knowledge of past times from a study of their existing remains? If so, let us travel to a ravine or coulee, where there is a nice spring of vater not too far away -and dig.

I did this in 1940 in just such a ravine about eight miles west of Bulyea, Sask. I was walking along the bottom of this ravine and came to soine mole hills. Being observant, I noticed these mole hills contained small pieces of bone. This seemed unusual so I took my shovel and tried to dig. To my surprise I found the bones to be so thick that I couldn't dig with a shovel and had to get a pick. Armed with these tro instruments and a screen I rent to work.

I soon found some small flint arrow heads and some buffalo rib bones, cut in about four inch lengths. These vere hollowed out at one end to make handles for holding sinall scrapers and knives. Some of these handles were plain; some were decorated with notches; some with drawings of fish and one had a wolf or coyote carved on it.

This find turned out to be a "Midden", or Buffalo Pound. This is a place where the Indians made a corral and drove two or three hundred buffalo into it for slaughter. The Indians then camped there and tanned the hides and dried the meat for future use. That is the reason for finding so many artifacts on these sites. At this site, digging during my spare time for three years I found twenty-three hundred specimens, These are now in the National luseum, at Ottara.

There are still lots of sites to be investigated. Itwould be appreciated if all new finds were reported to our Provincial Ifuseum. 


\section{HISTORIC SITES}

"The most historic site around here," vrites liarion llixon of Tauchope, "is the old Cannington Nanor settlement, west of Parkman, north of Manor and east of Moose llountains. There is a lot of almost legend about it now in local annals.

The town was dissipated when the railway failed to come through the site. (Legend has it, it was dissipated, period.). Some of the old Nanor houses are still standing, but many have suffered fires or other despoilation. The mill vas used as luraber, and only a nass of iron junk remains to mark it. The church, though, is well kept and still used. If only one had time for a canvass of the remaining oldtimers, before they are all gone, there would be tales to be recorded and pictures to save for posterity. Mrs. Herrett has done considerable along this line. Some of her data is on file at the University of Saskatchevan.

The following letter was received from Dr. R. C. Russell, of the University of Saskatchewan.

"I rould like to draw your attention to that I consider a mistake on page 8 of the April to September issue of the BLUE JAY. It is the third item under Tild Life, Punnichy: Mrs. Madeline B. Runyan." (The paragraph referred to is as follows: "A cairn is suggested to mark the site of the first Hudison Bay post in the Touchwood Hills. Until a fer years ago the stone chimney stood. This spot is five miles from the Runyan Farm." ED.)

"The stone chimney stood on the site of the third Hudson's Bay Company post, along highway No. 15 between Lestock and Punnichy, until a few years ago, It was built about 1874 and remained in use until about 1909.

The first post, $(1852$ - 1861), was built about six miles north and two miles west of Punnichy, according to Mr. Fred lorris, formerly Indian Interpreter at the Indian agency, just north of Punnichy. He has shown me this site along the old Carlton Trail.

The second site (186I - 1874) was about seven miles south of Punnichy near the Gordon Mission. The three posts are described in the Canadiah Geographic Society Journal, published about 1933.

I believe nothing has remained to mark the sites of the first two Touchwood Hills Hudson Bay posts, but the cellars, for many years." 